\title{
Structure, growth and production of a remarkably abundant population of the common goby, Pomatoschistus microps (Actinopterygii: Gobiidae)
}

\author{
A. T. Souza • E. Dias • J. Campos • J. C. Marques $\cdot$ I. Martins
}

Received: 26 December 2011 / Accepted: 5 August 2013 / Published online: 21 August 2013

(C) Springer Science+Business Media Dordrecht 2013

\begin{abstract}
The common goby, Pomatoschistus microps, is a relevant species from estuarine food webs, playing important roles as predator of polychaetes and crustaceans and as prey for larger fishes and crustaceans. The Minho estuary (NW Portugal) is a relatively wellpreserved and productive system. To assess the population structure and production of $P$. microps in this estuary, monthly samples were undertaken in three different areas along an estuarine gradient in the lower estuary. The density of $P$. microps varied considerably among seasons and sampling stations, with higher densities occurring in summer and autumn. The lowest densities were found closer to the sea. In general, the density of females was higher than the density of males in all sampling stations, while juveniles were more
\end{abstract}

Electronic supplementary material The online version of this article (doi:10.1007/s10641-013-0172-0) contains supplementary material, which is available to authorized users.

A. T. Souza $(\bowtie) \cdot$ E. Dias $\cdot$ J. Campos

CIMAR/CIIMAR - Centro Interdisciplinar de Investigação

Marinha e Ambiental, Universidade do Porto,

Rua dos Bragas 289, 4050-123 Porto, Portugal

e-mail: allantsouza@gmail.com

A. T. Souza $\cdot$ E. Dias

ICBAS - Instituto de Ciências Biomédicas de Abel Salazar,

Universidade do Porto,

Lg. Prof. Abel. Salazar, 2, 4099-003 Porto, Portugal

J. C. Marques · I. Martins

IMAR - CMA, Institute of Marine Research - Marine and Environmental Research Centre, Department of Life

Sciences, University of Coimbra,

3004-517 Coimbra, Portugal abundant within a salt marsh area. Compared with other European estuaries, our data showed a remarkable higher density and production values of P. microps. This may be related to the high freshwater input and the low salinities found in this estuary. In addition, we hypothesize that the lower density of the sympatric species $P$. minutus and the high availability of bivalve shells observed in the Minho estuary may have also contributed to the present results, once $P$. minutus and $P$. microps often display a diet overlap and the bivalve shells are crucial for the common goby reproduction.

Keywords Corbicula fluminea $\cdot$ Life cycle $\cdot$ Minho Pomatoschistus minutus $\cdot$ Secondary production

\section{Introduction}

Estuaries contain diverse aquatic habitat types, including seagrass, kelp and shellfish beds, muddy and sandy environments, among others (Nelson and Monaco 2000). These are highly biologically productive ecosystems that provide important forage, spawning, refuge, and nursery habitat for several fish species at various stages in their development (Chambers 1992; Nelson and Monaco 2000; Able 2005).

The Minho estuary (NW Iberian Peninsula) is a relatively well-preserved system where several aquatic species present higher values of density and/or secondary production compared with other systems (see Sousa et al. 2008a; Freitas et al. 2009; Dolbeth et al. 2010; Freitas 2011; Souza et al. 2013). In this estuary, 
five species of Gobiidae are present, namely, the common goby, Pomatoschistus microps, the sand goby $P$. minutus, the painted goby, $P$. pictus, the transparent goby, Aphia minuta and the black goby, Gobius niger, with P. microps being largely more abundant than other Gobiidae species (Antunes pers. comm.; Antunes and Rodrigues 2004; Costa-Dias et al. 2010).

The common goby is a small-bodied demersal euryhaline species that usually occurs in high densities, from Norway to Mauritania, including the Canary Islands, western Mediterranean and Baltic Sea, spanning ca. $44^{\circ}$ of latitudinal range (Froese and Pauly 2010). This species is of great importance in marine and estuarine ecosystems as it links low and high levels of the foodweb, by acting as a mesopredator, thus connecting microbenthos to larger predators such as birds and fishes (Doornbos 1984; Moreira et al. 1992; Cabral 2000).

The ecology of P. microps has been the focus of several studies, which include population structure (Arruda et al. 1993; Pampoulie 2001; Leitão et al. 2006; Dolbeth et al. 2007), breeding behavior (Magnhagen 1998; Pampoulie et al. 2000; Pampoulie 2001) and diet (Mehner 1992; Leitão et al. 2006; Jackson and Rundle 2008). However, few studies have focused on P. microps populations from the Atlantic coast of Southern Europe (but see Arruda et al. 1993; Leitão et al. 2006; Dolbeth et al. 2007). Besides, in this area, nearly $55 \%$ of published studies regarding the species focused on ecotoxicology (e.g., Monteiro et al. 2007; Vieira et al. 2008, 2009; Guimarães et al. 2012; Oliveira et al. 2012).

The common goby is often reported as one of the most abundant fish in estuaries (Martinho et al. 2007; Dolbeth et al. 2010), and it is frequently found in areas where the sympatic species $P$. minutus co-occurs. Both species are often found in equal or slightly different densities (e.g., Arruda et al. 1993; Leitão et al. 2006; Dolbeth et al. 2007; Martinho et al. 2007). However, in the Minho estuary, the common goby seems to be much more abundant than the sand goby (pers. obs.; CostaDias et al. 2010).

In this context, the present study aims at assessing the population structure, density, production and growth of P. microps in the Minho estuary. By focusing on the distributional patterns of $P$. microps within a system where the species seems to be especially abundant, we expect to increase the understanding of the ecology of this core species in several estuarine systems across Europe.

\section{Materials and methods}

Study area and sampling procedures

This study was conducted in the Minho estuary (NW of the Iberian Peninsula $-41^{\circ} 53^{\prime} \mathrm{N} 8^{\circ} 50^{\prime} 0$ ), which ranges up to $40 \mathrm{~km}$ (considering the upstream limit of spring tides), covering a total area of $23 \mathrm{~km}^{2}$. The Minho estuary is a very shallow system (Moreno et al. 2005), with a mean depth of $2.6 \mathrm{~m}$ (Freitas et al. 2009); it is characterized as a mesotidal and partially mixed system, although it tends towards a salt wedge estuary during periods of high river flow (Sousa et al. 2005).

This study was carried out during 18 months, from February/09 to July/10, with months being grouped into four seasons, namely winter (January, February and March), spring (April, May and June), summer (July, August and September) and autumn (October, November and December). Sampling was carried out in 3 nearby stations within the first $8 \mathrm{~km}$ of the Minho estuary, considering a gradient of distance to the river mouth (Fig. 1). The 3 stations (S1, S2 and S3) were chosen in order to assess possible dissimilarities on the population dynamics related to differences in habitat type and environmental parameters. S1 was closer to the river mouth $(c a .1 .5 \mathrm{~km})$, and characterized by the presence of soft bottoms, often densely covered by debris such as drifting seaweeds, dead leaves and empty mollusks' shells (Souza et al. 2011). S2 was located inside a salt marsh ( $c a .3 .5 \mathrm{~km}$ upwards from the river mouth), which is a relatively small system characterized by the presence of narrow channels, typically bordered by the seagrass, Spartina maritima. The channel's soft bottoms are often sparsely covered by debris and empty peppery furrow shells, Scrobicularia plana (Souza et al. 2011). S3 was located ca. $5 \mathrm{~km}$ upstream from S2, and characterized by high densities of the Asian clam, Corbicula fluminea, with the soft bottoms often sparsely covered by debris and submerged vegetation (Sousa et al. 2008b, c; Souza et al. 2013). In each site, with monthly periodicity, 3 replicates were collected using a $1 \mathrm{~m}$ beam trawl ( $5 \mathrm{~mm}$ mesh size) towed at constant speed $\left(2 \mathrm{~km} \cdot \mathrm{h}^{-1}\right)$ for 2 to $3 \mathrm{~min}$, during daylight at the high tide of spring tides. Previous studies in the Minho estuary indicated that the sampling area covered by a 3 -min tow, at constant speed, was equivalent to 100 $\pm 4 \mathrm{~m}^{2}$ on average (Freitas et al. 2009). Density data was standardized to the same scale (ind. $100 \mathrm{~m}^{-2}$ ) prior to the 
statistical analyses. Additionally, at each site, water temperature, salinity, $\mathrm{pH}$ and oxidation reduction potential (ORP) were measured at $20 \mathrm{~cm}$ above the bottom with a multiparameter probe YSI 6820 (two replicates).

The monthly river discharge data measured at Foz do Mouro hydrometric station between February/09 and July/10 was obtained from the INAG - Instituto da Água, I.P. (http://snirh.inag.pt).

\section{Laboratory procedures}

At each sampling date, the density of P. microps was determined by counting all sampled individuals. The size (total length - TL) of each fish was measured (0.01 $\mathrm{mm}$ precision) using a digital caliper, and subsequently assigned into one of the following seven size classes: A $(<15.00 \mathrm{~mm}), \mathrm{B}(15.01$ to $20.00 \mathrm{~mm}), \mathrm{C}$ (20.01 to $25.00 \mathrm{~mm}$ ), D (25.01 to
$30 \mathrm{~mm}) ; \mathrm{E}$ (30.01 to $35.00 \mathrm{~mm}), \mathrm{F}$ (35.01 to $40.00 \mathrm{~mm})$ and $\mathrm{G}(>40.01 \mathrm{~mm})$.

Fifty randomly selected individuals of each sample were observed under a magnifying glass for sex distinction based upon dimorphic features on their morphology and gonads (Whitehead et al. 1986). Individuals smaller than $26 \mathrm{~mm}$ of $\mathrm{T} L$ showed no clear morphological signs of their sex, and thus were considered sexually immature and classified as juveniles (see Bouchereau et al. 1989). Females with advanced stage of gonad development (i.e. presence of eggs) were assigned as ovigerous females. The total density of juveniles, males and females was estimated based on the percentage of contribution of each group within the fifty randomly selected fishes at each sample.

Additionally, 291 randomly selected fish from the three sampling stations were wet weighted in a precision scale to the nearest $0.001 \mathrm{~g}$ in order to determine the length-weight relationship. The

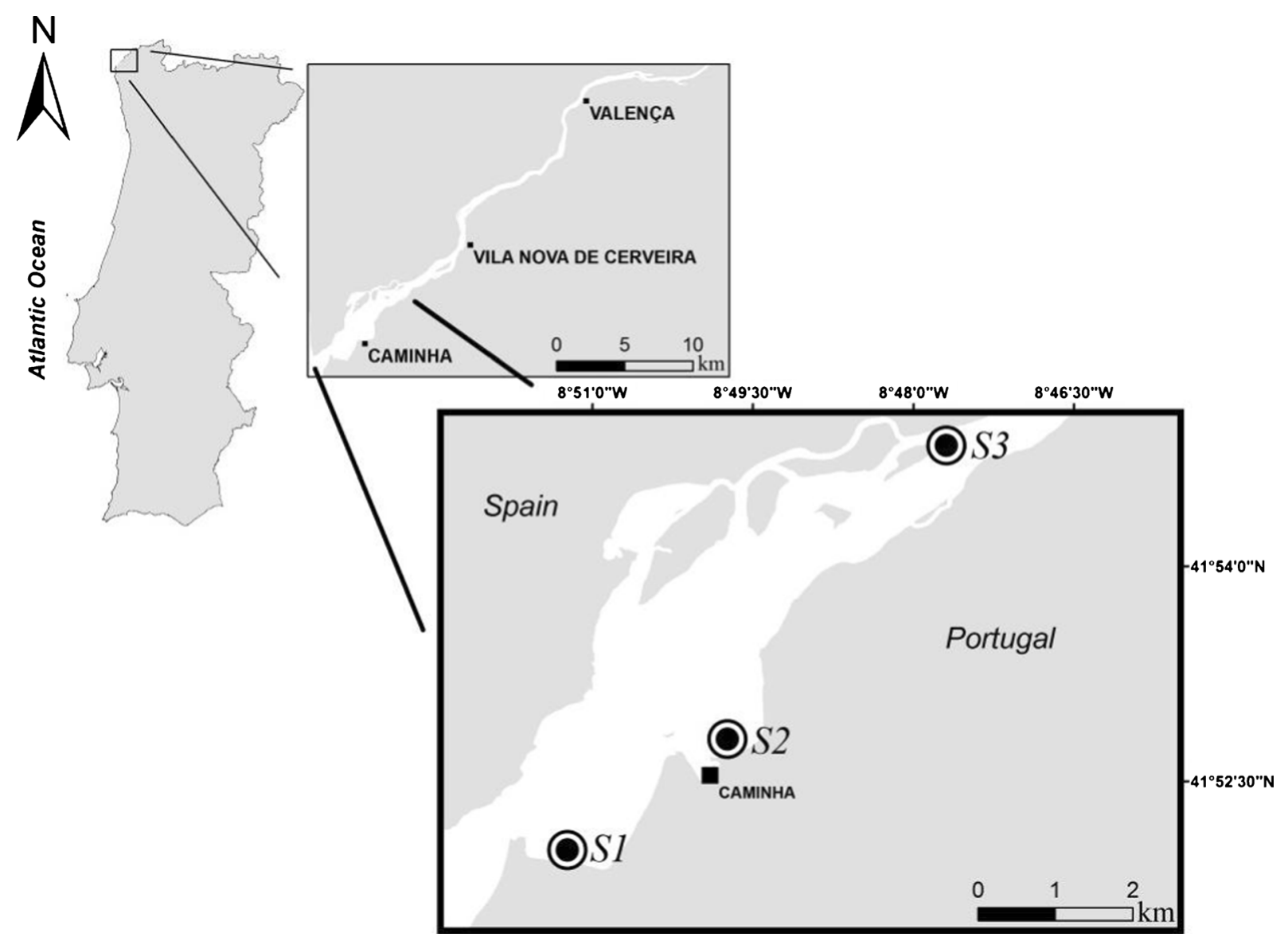

Fig. 1 Sampling stations on the lower Minho Estuary (NW Iberian Peninsula) 
condition factor of $P$. microps was calculated using the allometric equation:

$W=a \cdot L^{b}$

where $\mathrm{W}$ is the wet weight of the fish (in grams), $L$ is the total length of the fish (in centimeters) and $a$ and $b$ refer to the allometric coefficients obtained through the length-weight relationship (Reiss 1989).

\section{Data analysis}

Prior to the analyses of abiotic data, all variables were normalized. Posteriorly, a resemblance matrix based on the Euclidean distance was calculated. Principal Components Analysis (PCA) was performed in order to detect habitat differences among sampling stations based on environmental data.

A two-way SIMPER routine was applied to determine the contribution of each abiotic variable for the dissimilarities among groups of stations and seasons.

Afterwards, a Permutational Multivariate Analysis of Variance (PERMANOVA) (type-III) was employed in a two-way crossed design, with station as a fixed factor (3 levels: S1, S2 and S3) and season as a fixed factor (4 levels: winter, spring, summer and autumn), in order to test the statistical significant differences among sampling stations and seasons using all abiotic variables (multivariate approach) and comparing each variable separately (univariate approach). The PERMANOVA analysis is capable of handling unbalanced statistical designs, such as in this study (due to unequal number of samples collected in each season), and calculates an identical $F$ statistic that would be produced using traditional ANOVA and it is not affected by non-normal distribution of data (Anderson 2001).

A similar analysis procedure was adopted to investigate the common goby data. Prior to the analyses, all variables were normalized, and resemblance matrices based on Euclidean distance were calculated. The overall density, the density of each gender (juvenile, male and female), the density of ovigerous females, the density of P. microps size classes, the size of juveniles, males and females and the size of ovigerous females were statistically tested using a two-way PERMANOVA (type-III) in a two-way crossed design, with station as a fixed factor (3 levels: S1, S2 and S3) and season as a fixed factor (4 levels: winter, spring, summer and autumn), using both multivariate and univariate approaches (comparing each variable separately).

In PERMANOVA, the statistical significance of variance components was tested using 9999 permutations of residuals under a reduced model. When the possible number of permutations was lower than 150, the Monte Carlo-p value was considered. Subsequently, significant terms and interactions were investigated using a posteriori pairwise comparisons to determine which pairs of stations and seasons were significantly different.

In order to assess the influence of the abiotic variables on the abundance and distribution of P. microps' males, females and juveniles, a distance-based linear modeling (DistLM) was performed (Anderson et al. 2008). The selection criterion adopted was the AIC (Akaike Information Criterion), and a step-wise selection procedure was used, which optimizes selection of variables explaining most variation in the biotic data. The direction and magnitude of the relationship between abiotic variables and males, females and juveniles were displayed using distance based redundancy analysis (dbRDA) biplots (Legendre and Anderson 1999).

The PCA, the SIMPER, the PERMANOVA, the DistLM and the dbRDA analyses were performed using PRIMER v 6.1.11 ${ }^{\circledR}$ (Clarke and Gorley 2006) with PERMANOVA+1.0.1. add-on package (Anderson et al. 2008).

The population structure of $P$. microps was defined by tracking recognizable cohorts from the successive sampling dates. Spatial samples were pooled together and analyzed using the size frequency distribution of successive dates. The mixture analysis method was used to identify cohorts within size frequency distributions constructed from population samples in each month using the PAST ${ }^{\circledR}$ software. The mixture analysis is a maximum-likelihood method for estimating the parameters (mean, standard deviation and proportion), of univariate normal distributions, based on a pooled univariate sample. This software uses the EM algorithm described by Dempster et al. (1977) and considers a histogram of frequency as a mixture of probability density functions. The number of modes in each month was determined by visual analysis of the histogram.

Absolute growth rates (AGR, mm day ${ }^{-1}$ ) were determined for each cohort according to:

$A G R=\frac{L_{t 2}-L_{t 1}}{t_{2}-t_{1}}$ 
where $L_{\mathrm{t} 2}$ and $L_{\mathrm{t} 1}$ are the total length at time $\mathrm{t}_{2}$ and $\mathrm{t}_{1}$ respectively.

Finally, the secondary production was computed using the size-frequency method (Hynes method). This method calculates production by summing the biomass lost between size classes (Krueger and Martin 1980). In order to determine the production of P. microps in the lower Minho estuary, the Krueger and Martin (1980) equation was applied:

$$
\begin{gathered}
P=\sum_{j=1}^{a-1} 0.5\left[\left(Y_{i, j}+Y_{i+1, j}\right)-\left(Y_{i, j+1}+Y_{i+1, j+1}\right)\right] . \\
\left(W_{j} \cdot W_{j+1}\right) \cdot(t)^{-1}
\end{gathered}
$$

where $P$ is the annual production of the species, $Y_{i, j}$ is the mean density (ind. $\mathrm{m}^{-2}$ ) of the size class $j$ in the date $i, Y_{i+1, j}$ is the mean density of the size class $j$ in the date $i+1, Y_{i, j+1}$ is the mean density of the size class $j+1$ in the date $i, Y_{i+1, j+1}$ is the mean density of the size class

Table 1 Values of the five environmental variables (mean $\pm \mathrm{SE}$ ) measured in the three sampling stations throughout the seasons in the lower Minho estuary, NW Iberian Peninsula and the two-way $j+1$ in the date $i+1, W_{j}$ is the biomass $\left(\mathrm{g} . \mathrm{m}^{-2}\right)$ of the size class $j, W_{j+1}$ is the biomass of the size class $j+1$ and $\mathrm{t}$ is the time between $i$ and $i+1$. Population production estimates correspond to the sum of each size class production $(P)$. Negative production values were not included in the overall estimates and were regarded as zero production.

Annual production was calculated by a crossmultiplication, based on the values obtained for the overall production (18 months).

\section{Results}

\section{Abiotic data}

The two-way PERMANOVA for stations and seasons of all abiotic variables was significant for both main

PERMANOVA results on the effects of sampling stations and seasons and their interaction term

Two-way PERMANOVA

\begin{tabular}{|c|c|c|c|c|c|c|c|}
\hline & Winter & Spring & Summer & Autumn & Stations & Seasons & Interaction \\
\hline \multicolumn{8}{|l|}{ Depth } \\
\hline $\mathrm{S} 1$ & $4.2 \pm 0.3^{\mathrm{ac}(\mathrm{A})}$ & $3.1 \pm 0.3^{\mathrm{b}(\mathrm{A})}$ & $3.7 \pm 0.2^{\mathrm{ab}(\mathrm{A})}$ & $4.3 \pm 0.1^{\mathrm{c}(\mathrm{A})}$ & \multirow[t]{3}{*}{ Pseudo- $F=57.78^{*} *$} & \multirow[t]{3}{*}{ Pseudo- $F=6.87^{* *}$} & \multirow[t]{3}{*}{ Pseudo- $F=0.97^{\mathrm{ns}}$} \\
\hline $\mathrm{S} 2$ & $1.9 \pm 0.2^{\mathrm{a}(\mathrm{B})}$ & $1.3 \pm 0.2^{\mathrm{a}(\mathrm{B})}$ & $1.8 \pm 0.1^{\mathrm{a}(\mathrm{B})}$ & $1.8 \pm 0.1^{\mathrm{a}(\mathrm{B})}$ & & & \\
\hline $\mathrm{S} 3$ & $2.7 \pm 0.4^{\mathrm{a}(\mathrm{B})}$ & $1.9 \pm 0.3^{\mathrm{a}(\mathrm{B})}$ & $2.8 \pm 0.3^{\mathrm{a}(\mathrm{C})}$ & $2.1 \pm 0.1^{\mathrm{a}(\mathrm{B})}$ & & & \\
\hline \multicolumn{8}{|l|}{ ORP } \\
\hline $\mathrm{S} 1$ & $180.8 \pm 37.6$ & $156.1 \pm 28.9$ & $144.4 \pm 36.3$ & $169.2 \pm 27.0$ & \multirow[t]{3}{*}{ Pseudo- $F=0.09^{\mathrm{ns}}$} & \multirow[t]{3}{*}{ Pseudo- $F=0.57^{\mathrm{ns}}$} & \multirow[t]{3}{*}{ Pseudo- $F=0.02^{\mathrm{ns}}$} \\
\hline $\mathrm{S} 2$ & $189.1 \pm 45.6$ & $153.6 \pm 32.0$ & $159.5 \pm 41.5$ & $173.4 \pm 19.0$ & & & \\
\hline $\mathrm{S} 3$ & $201.2 \pm 52.2$ & $159.9 \pm 31.5$ & $167.2 \pm 43.7$ & $170.6 \pm 26.7$ & & & \\
\hline \multicolumn{8}{|l|}{$\mathrm{pH}$} \\
\hline $\mathrm{S} 1$ & $7.8 \pm 0.2^{\mathrm{a}}$ & $7.8 \pm 0.3^{\mathrm{a}}$ & $8.5 \pm 0.3^{\mathrm{a}}$ & $8.0 \pm 0.2^{\mathrm{a}}$ & \multirow[t]{3}{*}{ Pseudo- $F=0.39^{\mathrm{ns}}$} & \multirow[t]{3}{*}{ Pseudo- $F=8.77^{* *}$} & \multirow[t]{3}{*}{ Pseudo- $F=0.20^{\mathrm{ns}}$} \\
\hline $\mathrm{S} 2$ & $7.8 \pm 0.2^{\mathrm{a}}$ & $8.0 \pm 0.2^{\mathrm{ab}}$ & $8.8 \pm 0.3^{b}$ & $8.1 \pm 0.3^{\mathrm{ab}}$ & & & \\
\hline $\mathrm{S} 3$ & $7.7 \pm 0.1^{\mathrm{a}}$ & $8.1 \pm 0.2^{\mathrm{ab}}$ & $8.9 \pm 0.3^{b}$ & $8.1 \pm 0.2^{\mathrm{ab}}$ & & & \\
\hline \multicolumn{8}{|c|}{ Salinity } \\
\hline $\mathrm{S} 1$ & $25.8 \pm 6.5^{\mathrm{a}(\mathrm{A})}$ & $26.0 \pm 2.9^{\mathrm{a}(\mathrm{A})}$ & $32.0 \pm 1.0^{\mathrm{a}(\mathrm{A})}$ & $31.8 \pm 1.9^{\mathrm{a}(\mathrm{A})}$ & \multirow[t]{3}{*}{ Pseudo- $F=22.83^{* *}$} & \multirow[t]{3}{*}{ Pseudo- $F=5.77^{*}$} & \multirow[t]{3}{*}{ Pseudo- $F=0.55^{\mathrm{ns}}$} \\
\hline $\mathrm{S} 2$ & $12.8 \pm 7.8^{\mathrm{a}(\mathrm{AB})}$ & $15.9 \pm 6.2^{\mathrm{a}(\mathrm{A})}$ & $30.8 \pm 1.9^{\mathrm{a}(\mathrm{A})}$ & $23.0 \pm 6.9^{\mathrm{a}(\mathrm{AB})}$ & & & \\
\hline $\mathrm{S} 3$ & $0.4 \pm 0.2^{\mathrm{a}(\mathrm{B})}$ & $0.4 \pm 0.2^{\mathrm{a}(\mathrm{B})}$ & $19.1 \pm 4.2^{\mathrm{b}(\mathrm{B})}$ & $4.3 \pm 4.2^{\mathrm{ab}(\mathrm{B})}$ & & & \\
\hline \multicolumn{8}{|c|}{ Temperature } \\
\hline $\mathrm{S} 1$ & $11.9 \pm 0.9^{\mathrm{a}(\mathrm{A})}$ & $14.6 \pm 0.5^{\mathrm{b}(\mathrm{A})}$ & $15.0 \pm 0.6^{\mathrm{b}(\mathrm{A})}$ & $15.8 \pm 0.4^{\mathrm{b}(\mathrm{A})}$ & \multirow[t]{3}{*}{ Pseudo- $F=0.27^{\mathrm{ns}}$} & \multirow[t]{3}{*}{ Pseudo- $F=21.63 * *$} & \multirow[t]{3}{*}{ Pseudo- $F=2.17^{\mathrm{ns}}$} \\
\hline $\mathrm{S} 2$ & $11.7 \pm 0.8^{\mathrm{a}(\mathrm{A})}$ & $16.4 \pm 0.9^{\mathrm{b}(\mathrm{A})}$ & $15.9 \pm 0.5^{\mathrm{b}(\mathrm{AB})}$ & $15.1 \pm 1.5^{\mathrm{b}(\mathrm{A})}$ & & & \\
\hline $\mathrm{S} 3$ & $9.6 \pm 0.8^{\mathrm{a}(\mathrm{A})}$ & $16.4 \pm 1.2^{\mathrm{b}(\mathrm{A})}$ & $18.3 \pm 1.2^{\mathrm{b}(\mathrm{B})}$ & $14.7 \pm 1.8^{\mathrm{b}(\mathrm{A})}$ & & & \\
\hline
\end{tabular}

Seasons

${ }^{*}=p<0.01 ;{ }^{* *}=p<0.001 ;{ }^{n s}=$ non-significant. Different letters indicates significant differences among them. Lower case letters refers to comparisons among seasons, while upper case letters in brackets refers to comparisons among sampling stations (Two-way PERMANOVA, pairwise test: $p<0.05$ ) 
effects (stations: pseudo- $F=8.83, p<0.001$; seasons: pseudo- $F=6.81, p<0.001$ ), but was not significant for the stations $x$ seasons interaction (pseudo- $F=0.53$, $p=0.97$ ).

Depth was significantly higher in S1 during all seasons. On the other hand, $\mathrm{pH}$ was significantly higher during summer compared to winter in S2 and S3. Salinity was higher in S1 during all seasons; and in S3, salinity was significantly higher during summer compared with other seasons. Temperature varied seasonally, with significant lower values being recorded during winter in all sampling stations The ORP values did not vary among sampling stations and seasons (Table 1).

The two-way SIMPER results revealed that $60 \%$ of the dissimilarity between S1 and S2 was explained by depth and ORP values; while the dissimilarity between S1 and S3 was mostly explained by salinity and depth. On the other hand, dissimilarity between S2 and S3 was mainly related to differences in ORP and salinity. This analysis also revealed that temperature was the abiotic parameter that most varied among seasons (ESM 1).

Additionally, the PCA routine indicated that the first two axis explained $62.3 \%$ of the variance among samples (PC1: eigenvalue $=1.71$, explain $34.2 \%$ of variation; PC2: eigenvalue $=1.40$, explain $28.1 \%$ ) and revealed marked differences between sampling stations, with S1 differing from the other stations, mainly due to its lower values of temperature and $\mathrm{pH}$ and higher values of depth and salinity (Fig. 2).

Common goby data

A total of 15,001 fishes were sampled (S2=59.9\%, $\mathrm{S} 1=21.4 \%$ and $\mathrm{S} 3=18.7 \%$ ), with $36.6 \%$ of these being caught during autumn, $33.0 \%$ in winter, $18.3 \%$, in spring and $12.1 \%$ in summer.

\section{Density patterns}

The mean density of P. microps in the Minho estuary, considering the entire sampling period and the 3 stations, was $118.3 \pm 14.7$ ind. $100 \mathrm{~m}^{-2}$ (mean $\pm \mathrm{SE}$ ). The density of $P$. microps varied throughout the sampling period, with higher values being found during the autumn (429.0 \pm 140.0 ind $100 \mathrm{~m}^{-2}$ in December/09) (Fig. 3a).

The density of $P$. microps varied significantly through space and time (stations: pseudo- $F=40.14$, $p<0.001$; seasons: pseudo- $F=18.89, p<0.001$; stations $x$ seasons interaction pseudo- $F=10.11, p<0.001$ ), with each sampling station presenting a different pattern. In S1, the density of $P$. microps was lower during the summer $\left(17.8 \pm 4.8\right.$ ind $\left.\cdot 100 \mathrm{~m}^{-2}\right)$ compared with other seasons (pairwise test: $p<0.05$ ). In $\mathrm{S} 2$ the density of
Fig. 2 PCA showing the differences of the environmental variables among sampling stations in the lower Minho Estuary, NW Iberian Peninsula

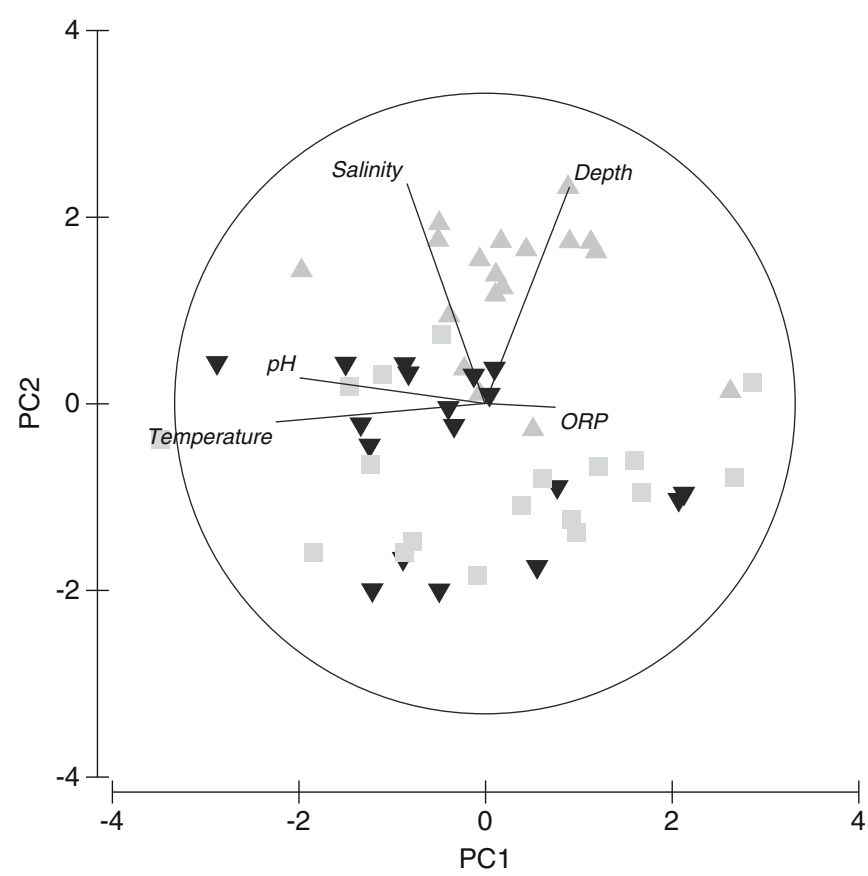



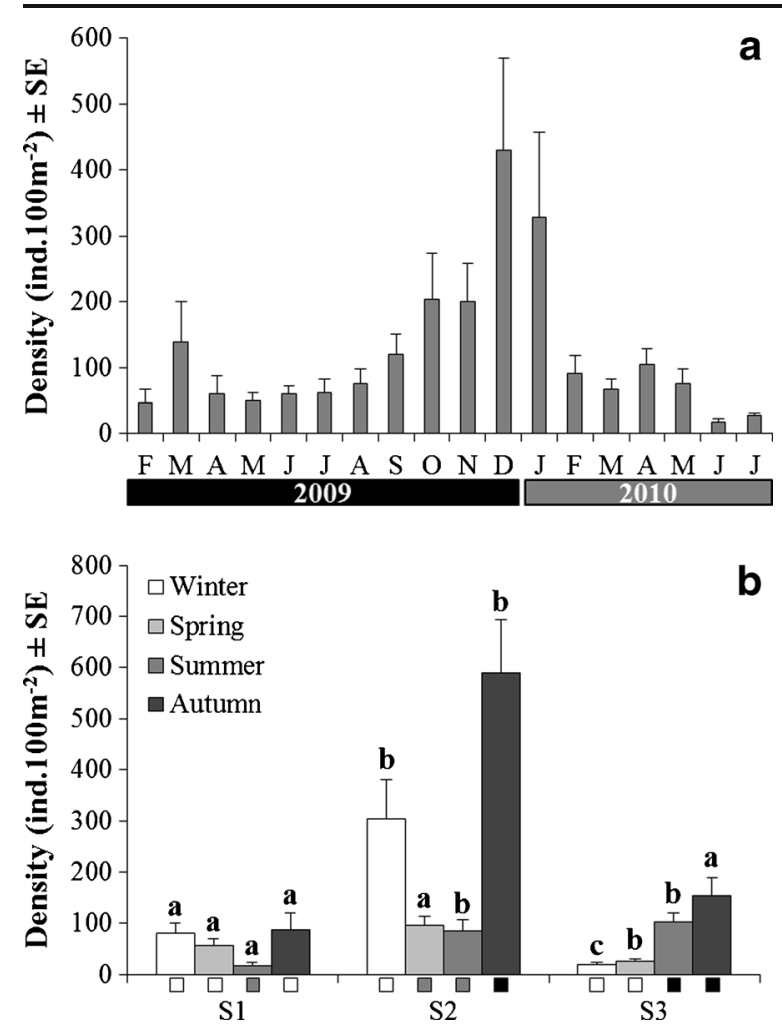

Fig. 3 a Mean density ( \pm SE) of the common goby, Pomatoschistus microps, during 18-months study period in Minho estuary. b Comparisons on the densities (mean $\pm \mathrm{SE}$ ) of $P$. microps between sampling stations and seasons. Different letters $(\mathbf{a}, \mathbf{b}$ or c) indicates post-hoc differences among sampling stations within the same season. Post-hoc differences among seasons within each sampling station are indicated by squares of different colors (white, grey or black) (Two-way PERMANOVA pairwise tests: $p<0.05)$

individuals was higher during the autumn (591.0 \pm 102.0 ind $\left.100 \mathrm{~m}^{-2}\right)$ and winter $(302.9 \pm 78.3$ ind $100 \mathrm{~m}^{-2}$ ) compared to spring and summer (pairwise test: $p<0.05$ ); whereas in $\mathrm{S} 3$, the common goby was more abundant during autumn and summer (pairwise test: $p<0.001$ ). Overall, the density of P. microps was higher in S2 during all seasons, except during summer, when S3 presented the highest density (102.0 \pm 18.4 ind $\cdot 100 \mathrm{~m}^{-2}$ ) (Fig. $\left.3 b\right)$.

The estimated densities of juveniles, males and females varied significantly through space and time [stations: pseudo- $F=25.08, p<0.001$; seasons: pseudo$F=11.79, \quad p<0.001 ;$ stations $x$ seasons interaction (pseudo- $F=7.03, p<0.001$ )]. Males and females were more abundant in S2 during all seasons, except in summer, when density was higher in S3. Juveniles, on the other hand, were denser in S2 during all seasons but spring, when the higher density was recorded in S1; with the lowest density value being recorded during summer in S1, spring in S2 and winter in S3 (Table 2).

The sampled population was dominated by females $(53.0 \%)$, with males and juveniles contributing with a smaller portion of individuals $(26.3 \%$ and $20.7 \%$ respectively). The sex ratio $(\mathrm{M} / \mathrm{F})$ was not significantly different for stations (pseudo- $F=0.62, p=0.55$ ), but was significant for seasons (pseudo- $F=10.34, p<0.001$ ) and for the stations $x$ seasons interaction (pseudo- $F=2.49$, $p<0.05$ ). The highest (spring: $1.7 \pm 0.4$ ) and the lowest (autumn: $0.2 \pm 0.1$ ) values of sex ratio were recorded in S2 (ESM 2).

A total of 349 ovigerous females were caught in 18 months, with 20 individuals in autumn (5.7\%), 41 in winter $(11.8 \%), 190$ in spring $(54.4 \%)$ and 98 in summer $(28.1 \%)$ with an average density of $2.2 \pm 0.3$ ind $100 \mathrm{~m}^{-2}$ (mean $\pm \mathrm{SE}$ ). The density of ovigerous females also varied through space and time (stations: pseudo- $F=2.14, p=0.12$; seasons pseudo- $F=5.91, p<0.01$; stations $x$ seasons interaction (pseudo- $F=2.71, p<0.05$ ), with higher densities being recorded during spring ( $\mathrm{S} 1$ and S2) and summer (S3) (Fig. 4).

Size and recruitment patterns

The range of $\mathrm{T} L$ varied between 9.3 and $71.4 \mathrm{~mm}$, with an average value of $30.4 \pm 0.1 \mathrm{~mm}$ (mean $\pm \mathrm{SE}$ ). The size of males did not vary significantly among sampling stations, but larger males were found during winter and autumn. On the other hand, the size of females varied significantly among sampling stations and seasons, with larger females being recorded in S3 during all seasons, except in autumn, when larger females were recorded in S1. Juveniles also presented significant differences among sampling stations and seasons, with smaller fish being recorded in S3 during all seasons, except in autumn, when smaller gobies were found in S1 (Table 3).

The $\mathrm{T} L$ of the ovigerous females varied between 26.8 and $46.9 \mathrm{~mm}$, with an average value of $35.9 \pm 0.2 \mathrm{~mm}$. The two-way PERMANOVA indicated that size of ovigerous females varied significantly among seasons (pseudo- $F=6.72, p<0.001$ ), but not among stations (pseudo- $F=0.11, p=0.73$ ); the stations $x$ seasons interaction was also non-significant (pseudo- $F=1.02$, $p=0.41$ ) (Table 4).

The density of the different size classes of $P$. microps varied through space and time (stations: 
Table 2 Comparisons on the estimated density (mean \pm SE) of males, females and juveniles of the common goby Pomatoschistus microps among three sampling stations and four seasons in Minho estuary, NW Iberian Peninsula

\begin{tabular}{|c|c|c|c|c|c|c|c|}
\hline & \multicolumn{4}{|l|}{ Seasons } & \multicolumn{3}{|c|}{ Two-way PERMANOVA } \\
\hline & Winter & Spring & Summer & Autumn & Stations & Seasons & Interaction \\
\hline \multicolumn{8}{|l|}{ Male } \\
\hline $\begin{array}{l}\mathrm{S} 1 \\
\mathrm{~S} 2\end{array}$ & $\begin{array}{l}20.5 \pm 4.6^{\mathrm{a}(\mathrm{A})} \\
51.0 \pm 11.6^{\mathrm{a}(\mathrm{B})}\end{array}$ & $\begin{array}{l}19.4 \pm 4.1^{\mathrm{a}(\mathrm{A})} \\
47.4 \pm 7.9^{\mathrm{a}(\mathrm{B})}\end{array}$ & $\begin{array}{l}6.0 \pm 1.5^{\mathrm{b}(\mathrm{A})} \\
6.2 \pm 1.4^{\mathrm{b}(\mathrm{A})}\end{array}$ & $\begin{array}{l}15.6 \pm 6.0^{\mathrm{ab}(\mathrm{A})} \\
61.3 \pm 10.1^{\mathrm{a}(\mathrm{B})}\end{array}$ & \multirow[t]{2}{*}{ Pseudo- $F=22.04 *$} & \multirow[t]{2}{*}{ Pseudo- $F=7.13^{*}$} & \multirow[t]{2}{*}{ Pseudo- $F=5.38^{*}$} \\
\hline $\mathrm{S} 3$ & $4.7 \pm 1.5^{\mathrm{a}(\mathrm{C})}$ & $8.3 \pm 2.5^{\mathrm{a}(\mathrm{C})}$ & $19.1 \pm 4.0^{\mathrm{b}(\mathrm{B})}$ & $32.1 \pm 7.4^{\mathrm{b}(\mathrm{A})}$ & & & \\
\hline \multicolumn{8}{|c|}{ Female } \\
\hline $\begin{array}{l}\text { S1 } \\
\text { S2 }\end{array}$ & $\begin{array}{r}46.6 \pm 12.2^{\mathrm{a}(\mathrm{A})} \\
156.1 \pm 42.4^{\mathrm{a}(\mathrm{B})}\end{array}$ & $\begin{array}{l}29.9 \pm 7.9^{\mathrm{a}(\mathrm{A})} \\
43.3 \pm 8.9^{\mathrm{b}(\mathrm{A})}\end{array}$ & $\begin{array}{c}7.4 \pm 2.0^{\mathrm{b}(\mathrm{A})} \\
43.5 \pm 18.0^{\mathrm{ab}(\mathrm{B})}\end{array}$ & $\begin{array}{r}57.7 \pm 25.0^{\mathrm{a}(\mathrm{A})} \\
370.0 \pm 63.8^{\mathrm{c}(\mathrm{B})}\end{array}$ & \multirow[t]{2}{*}{ Pseudo- $F=37.42^{*}$} & \multirow[t]{2}{*}{ Pseudo- $F=22.18^{*}$} & \multirow[t]{2}{*}{ Pseudo- $F=11.64^{*}$} \\
\hline S3 & $12.1 \pm 3.0^{\mathrm{a}(\mathrm{C})}$ & $12.0 \pm 3.3^{\mathrm{a}(\mathrm{B})}$ & $59.4 \pm 13.3^{\mathrm{b}(\mathrm{B})}$ & $80.7 \pm 21.1^{\mathrm{b}(\mathrm{A})}$ & & & \\
\hline \multicolumn{8}{|l|}{ venile } \\
\hline $\begin{array}{l}\text { S1 } \\
\text { S2 }\end{array}$ & $\begin{array}{l}12.7 \pm 4.2^{\mathrm{ab}(\mathrm{A})} \\
95.9 \pm 30.6^{\mathrm{ac}(\mathrm{B})}\end{array}$ & $\begin{array}{l}7.1 \pm 2.2^{\mathrm{ab}(\mathrm{A})} \\
6.3 \pm 2.5^{\mathrm{b}(\mathrm{A})}\end{array}$ & $\begin{array}{r}4.1 \pm 1.8^{\mathrm{a}(\mathrm{A})} \\
29.9 \pm 9.1^{\mathrm{a}(\mathrm{B})}\end{array}$ & $\begin{array}{c}14.1 \pm 4.3^{\mathrm{b}(\mathrm{A})} \\
160.2 \pm 53.4^{\mathrm{c}(\mathrm{B})}\end{array}$ & \multirow[t]{2}{*}{ Pseudo- $F=19.31^{*}$} & \multirow[t]{2}{*}{ Pseudo- $F=8.88^{*}$} & \multirow[t]{2}{*}{ Pseudo- $F=5.36^{*}$} \\
\hline S3 & $1.5 \pm 0.9^{\mathrm{a}(\mathrm{C})}$ & $4.8 \pm 2.0^{\mathrm{a}(\mathrm{A})}$ & $23.6 \pm 4.8^{\mathrm{b}(\mathrm{B})}$ & $40.4 \pm 24.5^{\mathrm{b}(\mathrm{A})}$ & & & \\
\hline
\end{tabular}

$*=p<0.001$. Different letters indicates significant differences among them. Lower case letters refers to comparisons among seasons, while upper case letters in brackets refers to comparisons among sampling stations (Two-way PERMANOVA, pairwise test: $p<0.05$ )

pseudo- $F=17.61, p<0.001$; seasons: pseudo- $F=11.47$, $p<0.001$; stations $x$ seasons interaction: pseudo$F=5.06, p<0.001)$. Results indicated that most of the size classes were more abundant in $\mathrm{S} 2$, except size class A, which was more abundant in S3. In S1 and $\mathrm{S} 3$, the most abundant size classes were E, D and F respectively, while classes $\mathrm{D}, \mathrm{E}$ and $\mathrm{C}$ were the most abundant in S2 (Fig. 5).

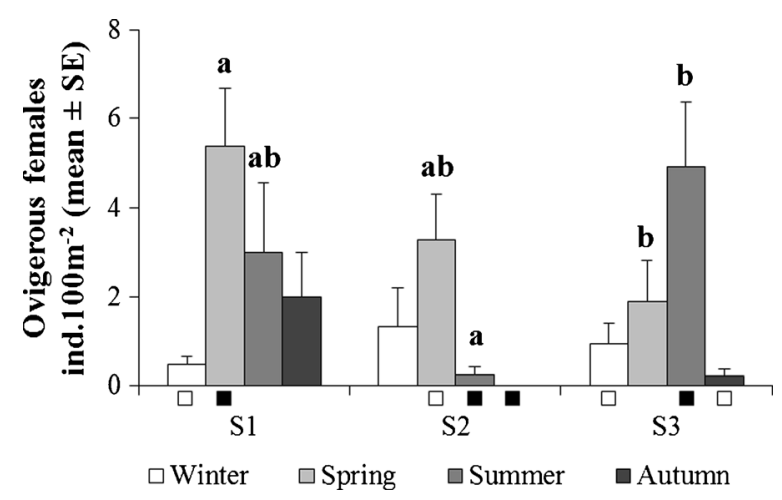

Fig. 4 Comparisons on the density (mean \pm SE) of ovigerous females of the common goby, Pomatoschistus microps, among three sampling stations and seasons in lower Minho estuary, NW Iberian Peninsula. Different letters (a or b) indicates post-hoc differences among sampling stations within the same season. Post-hoc differences among seasons within each sampling station are indicated by squares of different colors (white or black) (Two-way PERMANOVA pairwise tests: $p<0.05$ )
The mixture analysis indicated that the recruitment of $P$. microps occurred three times during the sampled period, twice in 2009 (May and October) and once in 2010 (June) (Fig. 6).

Fish-habitat associations

The DistLM results indicated that 3 of the 7 abiotic variables significantly influenced the abundance of $P$. microps males, females and juveniles. The river discharge, depth and distance from the river mouth were the best combination of predictor variables identified by the model and accounted for $22.6 \%$ of the total variance (Table 5).

The dbRDA explained less than $1 / 4$ of the variance, and within this scope, the model suggest that $P$. microps males were more abundant in shallow areas closer to the river mouth during months with high river discharge. On the other hand, P. microps females and juveniles showed little evidence of association with the significant abiotic variables (ESM 3).

Length-weight relationship, growth and secondary production

The calculated length and wet weight relationship of the $P$. microps presented a high allometric $\mathrm{b}$ value $(b=3.6489)$ and low allometric a value $(a=0.000001)$. 
Table 3 Comparisons on the total length (mean $\pm \mathrm{SE}$ ) of males and females of the common goby Pomatoschistus microps among sampling stations and seasons in Minho estuary, NW Iberian Peninsula

\begin{tabular}{|c|c|c|c|c|c|c|c|}
\hline & \multicolumn{4}{|c|}{ Total length (mm) } & \multicolumn{3}{|c|}{ Two-way PERMANOVA } \\
\hline & Winter & Spring & Summer & Autumn & Station & Season & Interaction \\
\hline \multicolumn{8}{|l|}{ Male } \\
\hline $\begin{array}{l}\text { S1 } \\
\text { S2 }\end{array}$ & $\begin{array}{l}36.7 \pm 0.5^{\mathrm{a}(\mathrm{A})} \\
37.4 \pm 0.4^{\mathrm{a}(\mathrm{AB})}\end{array}$ & $\begin{array}{l}34.0 \pm 0.3^{\mathrm{b}(\mathrm{A})} \\
34.5 \pm 0.3^{\mathrm{b}(\mathrm{A})}\end{array}$ & $\begin{array}{l}33.1 \pm 0.5^{\mathrm{b}(\mathrm{A})} \\
34.3 \pm 0.6^{\mathrm{b}(\mathrm{A})}\end{array}$ & $\begin{array}{l}37.3 \pm 1.0^{\mathrm{a}(\mathrm{A})} \\
36.8 \pm 0.8^{\mathrm{a}(\mathrm{A})}\end{array}$ & \multirow[t]{2}{*}{ Pseudo- $F=1.46^{\mathrm{ns}}$} & \multirow[t]{2}{*}{ Pseudo- $F=40.51^{*}$} & \multirow[t]{2}{*}{ Pseudo- $F=3.84 *$} \\
\hline $\mathrm{S} 3$ & $38.6 \pm 0.50^{\mathrm{a}(\mathrm{B})}$ & $36.1 \pm 0.4^{\mathrm{b}(\mathrm{B})}$ & $31.8 \pm 0.3^{\mathrm{c}(\mathrm{B})}$ & $36.8 \pm 0.6^{\mathrm{b}(\mathrm{A})}$ & & & \\
\hline \multicolumn{8}{|c|}{ Female } \\
\hline $\begin{array}{l}\text { S1 } \\
\text { S2 }\end{array}$ & $\begin{array}{l}33.1 \pm 0.3^{\mathrm{a}(\mathrm{A})} \\
32.4 \pm 0.2^{\mathrm{a}(\mathrm{A})}\end{array}$ & $\begin{array}{l}34.7 \pm 0.3^{\mathrm{b}(\mathrm{A})} \\
32.7 \pm 0.3^{\mathrm{a}(\mathrm{B})}\end{array}$ & $\begin{array}{l}32.5 \pm 0.6^{\mathrm{a}(\mathrm{A})} \\
30.1 \pm 0.3^{\mathrm{b}(\mathrm{B})}\end{array}$ & $\begin{array}{l}34.6 \pm 0.4^{\mathrm{b}(\mathrm{A})} \\
32.3 \pm 0.3^{\mathrm{a}(\mathrm{B})}\end{array}$ & \multirow[t]{2}{*}{ Pseudo- $F=86.87^{*}$} & \multirow[t]{2}{*}{ Pseudo- $F=30.47 *$} & \multirow[t]{2}{*}{ Pseudo- $F=7.06^{*}$} \\
\hline S3 & $35.5 \pm 0.4^{\mathrm{a}(\mathrm{B})}$ & $36.4 \pm 0.3^{\mathrm{b}(\mathrm{C})}$ & $33.1 \pm 0.3^{\mathrm{c}(\mathrm{A})}$ & $33.4 \pm 0.3^{\mathrm{c}(\mathrm{C})}$ & & & \\
\hline \multicolumn{8}{|c|}{ Juvenile } \\
\hline $\begin{array}{l}\text { S1 } \\
\text { S2 }\end{array}$ & $\begin{array}{l}25.7 \pm 0.4^{\mathrm{a}(\mathrm{A})} \\
24.2 \pm 0.3^{\mathrm{a}(\mathrm{B})}\end{array}$ & $\begin{array}{l}24.6 \pm 0.6^{\mathrm{a}(\mathrm{A})} \\
24.5 \pm 0.6^{\mathrm{a}(\mathrm{A})}\end{array}$ & $\begin{array}{l}21.8 \pm 0.4^{\mathrm{b}(\mathrm{A})} \\
23.5 \pm 0.3^{\mathrm{a}(\mathrm{B})}\end{array}$ & $\begin{array}{l}22.3 \pm 0.8^{\mathrm{b}(\mathrm{A})} \\
23.8 \pm 0.3^{\mathrm{a}(\mathrm{A})}\end{array}$ & \multirow[t]{2}{*}{ Pseudo- $F=21.06^{*}$} & \multirow[t]{2}{*}{ Pseudo- $F=26.87^{*}$} & \multirow[t]{2}{*}{ Pseudo- $F=49.04 *$} \\
\hline $\mathrm{S} 3$ & $23.6 \pm 0.5^{\mathrm{a}(\mathrm{B})}$ & $14.8 \pm 0.4^{\mathrm{b}(\mathrm{B})}$ & $21.3 \pm 0.4^{\mathrm{a}(\mathrm{A})}$ & $26.8 \pm 0.5^{\mathrm{c}(\mathrm{B})}$ & & & \\
\hline
\end{tabular}

${ }^{n s}=$ non-significant; $*=p<0.001$. Different letters indicates significant differences among them. Lower case letters refers to comparisons among seasons, while upper case letters in brackets refers to comparisons among sampling stations (Two-way PERMANOVA, pairwise test: $p<0.05)$

Growth of the $\mathrm{C} 2$ and $\mathrm{C} 3$ cohorts was similar, while individuals from the $\mathrm{C} 4$ cohort grew faster than others cohorts (Table 6).

The estimated overall secondary production of $P$. microps was $5.38 \mathrm{~g} \cdot \mathrm{WWm}^{-2}$, with an annual production of $3.83 \mathrm{~g} \cdot \mathrm{WWm}^{-2} \cdot \mathrm{year}^{-1}$.

\section{Discussion}

Common goby has a great capacity of adaptation, which allows it to successfully occupy habitats with different environmental characteristics (Bouchereau and Guelorget 1998). However, it seems that in the Minho estuary, the species preferentially occupied the salt marsh area (S2), since the density of $P$. microps at this station was constantly higher compared with its density at the river mouth (S1) and the upper station (S3). In the salt marsh area, most of the fishes were small-bodied, suggesting that this area may serve as a refuge or shelter site for juveniles and subadults. Actually as reported in other studies, the high complexity and productivity of salt marshes' biological communities might provide an ideal environment for feeding, sheltering and growing for the common goby (Koutsogiannopoulou and Wilson 2007). In contrast, at the river mouth (S1) most of the fishes were larger, with $\mathrm{ca} .70 \%$ of the individuals being sexually mature throughout the year. In the upper station (S3), the density of gobies varied considerably throughout seasons, with lower values being recorded during winter and spring, compared with summer and autumn. Such variations on $P$. microps density suggest that the upper station presented important seasonal oscillations in

Table 4 Comparisons on the total length (mean \pm SE) of ovigerous females of the common goby, Pomatoschistus microps, among sampling stations and seasons in Minho estuary, NW Iberian Peninsula

\begin{tabular}{lllll}
\hline Station $\backslash$ Season & Winter & Spring & Summer & Autumn \\
\hline S1 & $40.6 \pm 1.5^{\mathrm{a}(\mathrm{A})}$ & $35.9 \pm 0.4^{\mathrm{b}(\mathrm{AB})}$ & $34.9 \pm 0.7^{\mathrm{b}(\mathrm{A})}$ & $38.5 \pm 0.9^{\mathrm{a}(\mathrm{A})}$ \\
S2 & $35.7 \pm 0.9^{\mathrm{a}(\mathrm{B})}$ & $34.9 \pm 0.5^{\mathrm{a}(\mathrm{A})}$ & $32.3 \pm 1.8^{\mathrm{b}(\mathrm{A})}$ & - \\
S3 & $37.9 \pm 1.2^{\mathrm{a}(\mathrm{AB})}$ & $37.1 \pm 0.8^{\mathrm{a}(\mathrm{B})}$ & $35.3 \pm 0.5^{\mathrm{b}(\mathrm{A})}$ & $38.3 \pm 2.8^{\mathrm{ab}(\mathrm{B})}$ \\
\hline
\end{tabular}

Different letters indicates significant differences among them. Lower case letters refers to comparisons among seasons, while upper case letters in brackets refers to comparisons among sampling stations (Two-way PERMANOVA, pairwise test: $p<0.05$ ) 
abiotic variables and might be located near the upstream limit of distribution of the species in winter. Our results suggest that the area occupied by the common goby in the estuary might vary throughout the year due to different degrees of saline intrusion. During summer, the saline plume often reaches upstream areas of the estuary, noticeably influencing the distribution of the species. The saline intrusion in the Minho
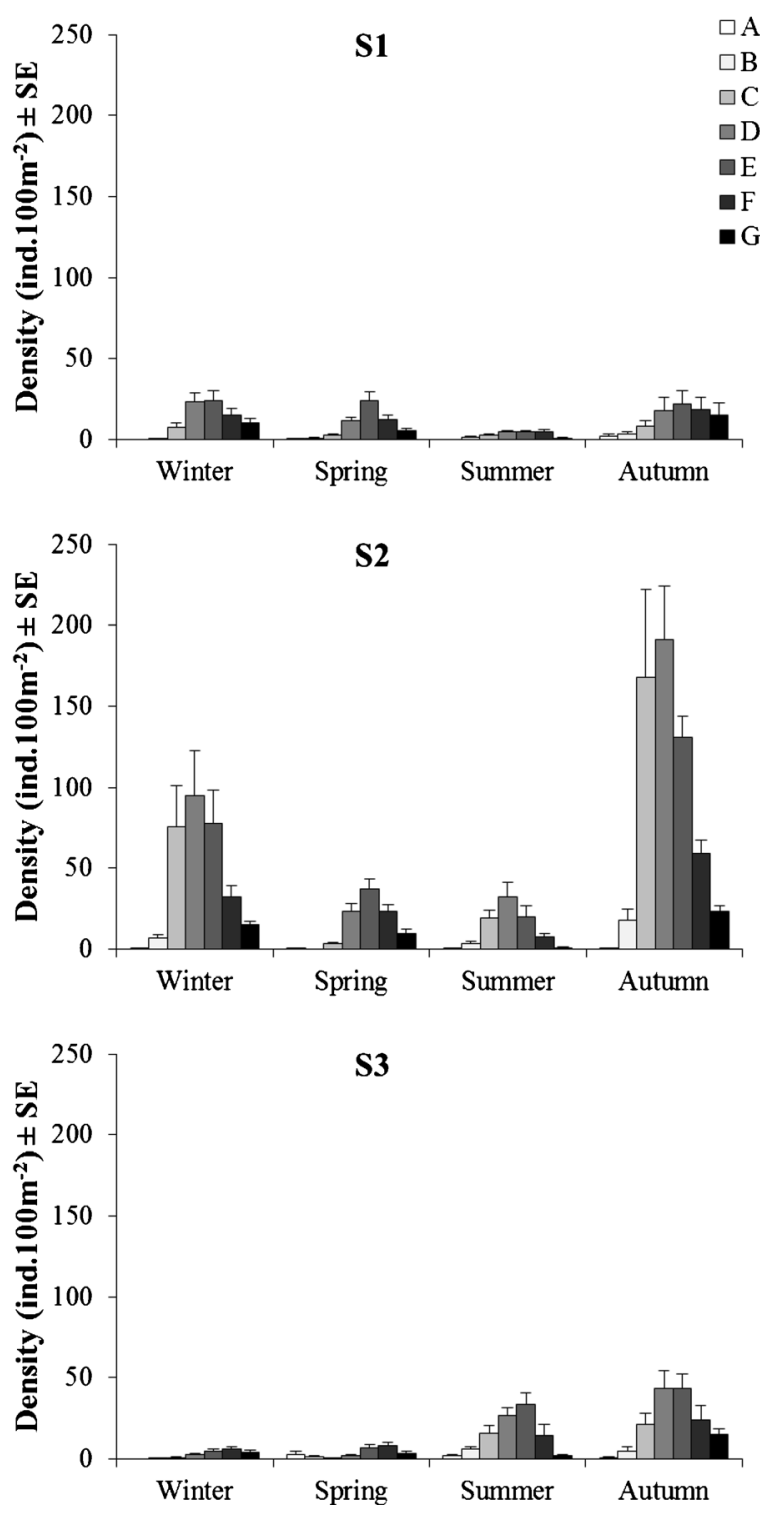

Fig. 5 Mean density ( \pm SE) of the seven size classes of the common goby, Pomatoschistus microps, among seasons in each sampling station of the lower Minho estuary, NW Iberian Peninsula. Size classes: a $(<15.00 \mathrm{~mm}), \mathbf{b}(15.01$ to $20.00 \mathrm{~mm})$, c (20.01 to $25.00 \mathrm{~mm}), \mathbf{d}(25.01$ to $30 \mathrm{~mm})$; $\mathbf{e}(30.01$ to $35.00 \mathrm{~mm})$, f (35.01 to $40.00 \mathrm{~mm})$ and $\mathbf{g}(>40.01 \mathrm{~mm})$

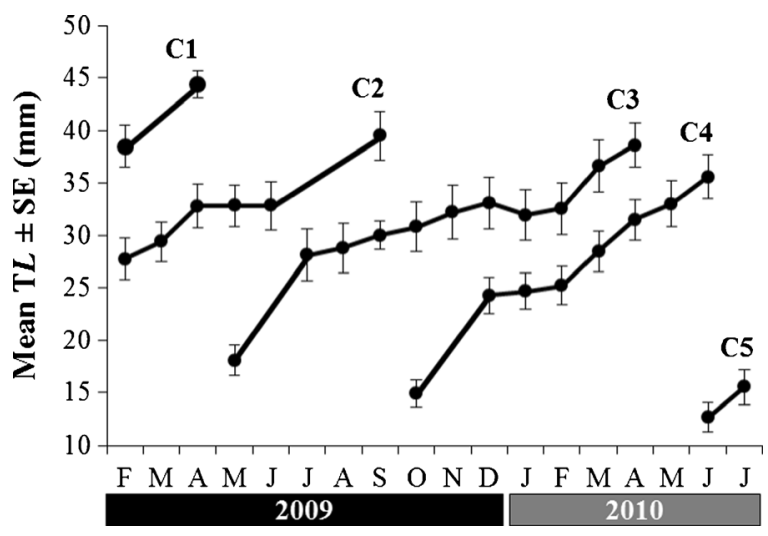

Fig. 6 Mean cohort length of the common goby, Pomatoschistus microps, in lower Minho estuary, with indication of the five cohorts identified by the mixture analysis $(\mathrm{C} 1, \mathrm{C} 2, \mathrm{C} 3, \mathrm{C} 4$ and C5)

estuary fluctuates between $10 \mathrm{~km}$ during winter and $20 \mathrm{~km}$ during summer, exceptionally ranging up to $30 \mathrm{~km}$ in extreme conditions (Antunes pers. comm.). In fact, during summer this species can be found in a much wider spectrum within the estuary, being recorded $c a .13 \mathrm{~km}$ upstream from the river mouth; whilst during winter, P. microps is usually restricted to the lowest areas of the estuary (ca. $9 \mathrm{~km}$ ) (pers. obs.).

The numerical dominance of females over males is relatively common in Pomatoschistus spp. populations (e.g., Bouchereau et al. 1993; Fouda et al. 1993; Koutrakis and Tsikliras 2009) and may be related to different behaviors exhibited by sexes. According to Miller (1984), during the breeding season, there is a marked reduction in the proportion of males due to their nest guarding behavior. P. microps males guard eggs under shells or stones, consequently males are less easily caught. In fact, males were less abundant during summer at the river mouth and at the salt marsh.

Differently from Leitão et al. (2006), which noted that $0+$ group associated with high temperatures, in our study, juveniles associated with colder waters, indicating that juveniles recruited in different months in Mondego and in Minho, two estuaries from the Atlantic coast of Portugal. According to the present study, recruitment occurred twice per year (in late spring/early summer and in the autumn), while in Mondego, P. microps recruited three times per year (winter, spring and summer) (Leitão et al. 2006). Notwithstanding, a third pattern was reported for the Minho and Mondego estuaries, with recruitment occurring once per year in Minho (in early summer), and 
Table 5 DistLM model based on the abundance of $P$. microps males, females and juveniles and fitted abiotic data

\begin{tabular}{llllll}
\hline \multicolumn{1}{l}{ Sequential tests } & \multicolumn{1}{l}{} \\
\hline Variable & AIC & $\begin{array}{l}\text { SS } \\
\text { (trace) }\end{array}$ & Pseudo- $F$ & $p$ & Prop. (\%) \\
\hline River discharge & 57.32 & 14.04 & 5.04 & $<0.05$ & 8.8 \\
$\begin{array}{l}\text { Depth } \\
\begin{array}{l}\text { Distance from } \\
\text { the mouth }\end{array}\end{array}$ & 54.23 & 13.05 & 5.05 & $<0.05$ & 8.2 \\
\hline
\end{tabular}

Prop. $=$ proportion of variation explained

twice (spring and summer) or three times (winter, spring and summer) per year in Mondego (Dolbeth et al. 2010). Actually, the recruitment of fishes in the Minho estuary often takes place later and growth rates are lower compared with the Mondego estuary, and those differences probably are related to differences in temperature between estuaries (Dolbeth et al. 2010). Also, in the present study, we found different growth rates among $P$. microps cohorts, with the autumn recruits $(\mathrm{C} 4)$ growing faster than the spring ones (C3). Different growth rates between fish cohorts in a given population are common and often related to environmental conditions, but their ecological causes and implications are still uncertain (e.g., Fuiman et al. 2005 and the references therein). However fast growing is often related to low temperatures (e.g., Dolbeth et al. 2010), which could explain the faster growth of autumn recruits compared with spring ones; since in spring water was slightly warmer than in autumn.

The observed differences in the density of ovigerous females may also indicate that breeding grounds varied seasonally within the estuary, probably due to differences in the temperature and in the availability of substrate for egg attachment, once each sampling station presented different substrate characteristics. The

Table 6 Absolute growth rates (AGR, mm.day ${ }^{-1}$ ) for the common goby, Pomatoschistus microps, cohorts

\begin{tabular}{lc}
\hline Cohort & Growth \pm CI \\
\hline C2 & $0.045 \pm 0.002$ \\
C3 & $0.046 \pm 0.001$ \\
C4 & $0.069 \pm 0.001$ \\
\hline
\end{tabular}

The AGR and the $95 \%$ confidence interval (CI) were computed only when the cohort was recorded for more than 3 months presence of bivalve shells is important for the species, since $P$. microps use them during the reproduction (Nyman 1953), and also for shelter. Thus, the high density of empty bivalve shells found in S3, can be related with the high density of ovigerous females found in this station during the summer, when most of the Asian clams $C$. fluminea die due to salinity increase (see Ilarri et al. 2011). In a small spatial scale experiment, Ilarri (2012) found that the densities of P. microps and $C$. fluminea were positively correlated, suggesting that the common goby prefers to inhabit areas with higher availability of bivalve shells in the Minho estuary.

P. microps is an iteroparous species (Miller 1984), being able to spawn several times along the reproductive cycle, normally spawning when water temperature is between 15 and $20^{\circ} \mathrm{C}$ (Wiederholm 1987). In the Minho estuary, the water temperature in the salt marsh and in the upper station varied within the optimal levels for $P$. microps reproduction from May to November, whereas in the river mouth, the optimum range of temperature occurred for a shorter period of time (from September to December). These results suggest that the reproduction of the common goby may occur in different periods of time in each estuarine section. It is also possible that the optimal temperature range for $P$. microps reproduction varies with latitude, once this species has a great plasticity on reproductive traits (Pampoulie et al. 2000; Dolbeth et al. 2010); however, due to the lack of data, this hypothesis cannot be confirmed or contradicted, and hence further studies are necessary to investigate if the optimal values suggested by Wiederholm (1987), based on individuals from the Bothnian Sea, are valid for P. microps populations in southern Europe.

Differences in recruitment periods obtained in this and other studies may also be related to the duration of the breeding season. In higher latitudes, breeding season is typically shorter than in lower latitudes, but in certain cases, breeding season can last longer in lower latitudes (see Bouchereau and Guelorget 1998). This seems to be the case of the Minho estuary, where the common goby presented a longer breeding season (6 months) than in estuaries located at higher latitudes (e.g., Miller 1975; Rogers 1988). Nevertheless, breeding season in the Minho estuary was also longer than in systems located in lower latitudes (e.g., Arruda et al. 1993; Leitão et al. 2006). A longer breeding season might have an important effect on the P. microps population, due to the improvement of its reproductive 
success (Bouchereau and Guelorget 1998), which would also help to explain the high densities recorded in the Minho estuary. In fact, the densities recorded in this study are much higher than those reported in southern (e.g., Leitão et al. 2006; Dolbeth et al. 2007; Martinho et al. 2007; Almeida et al. 2008; França et al. 2008) and in northern European estuaries (e.g., NorteCampos and Temming 1994; Selleslagh and Amara 2008) (Table 7). Latitudinal comparisons in P. microps density are difficult to be made, once the sampling strategies, techniques and periodicity are often different in each study. However, considering only studies that have adopted similar sampling methods, latitudinal trends become clearer. For instance, in studies which used encircling nets or traps (throw and drop), densities appear to be higher in northern compared with southern systems. Similarly, in studies that used beam trawls, fish density seems to be higher in higher latitudes. On the other hand, the densities recorded in the Minho estuary were much higher than elsewhere, suggesting that in this system, $P$. microps might find a combination of factors which helps it to achieve higher densities than would be expected, given the latitude of this estuary.

The common goby is sympatric with the sand goby P. minutus in several estuaries, and presents some degree of habitat and diet overlap (Leitão et al. 2006;
Złoch and Sapota 2010). Nevertheless, the sand goby is less tolerant to salinity and temperature fluctuations than the common goby, preferring to inhabit estuarine zones with higher salinities or the sea, whereas $P$. microps is preferentially found in brackish waters (Fonds and Van Buurt 1974; Pampoulie et al. 1999). In the Minho estuary, during winter, salinity can reach extremely low values even near the river mouth. For instance, in January/10, salinity at the bottom reached 0.12 in S1. The occurrence of such low salinities within the estuary may benefit $P$. microps by potentially expanding its favorable habitat and also by reducing the detrimental effects of competition with its congener P. minutus, which is much less abundant in areas with low salinities in this estuary (Souza et al. unpubl. data).

Also, the sampling strategy adopted in the present study may have contributed to the observed differences between population density in Minho and other estuaries, since we performed diurnal 1-m beam trawl catches, while other studies performed night catches using 2-m trawls. Changes in trawling time can result in differences on fish density (Rotherham et al. 2008) or not (Ribeiro et al. 2006); and as far as we know, there are no published studies that compare the efficiency of $1-\mathrm{m}$ and 2-m beam trawls for P. microps.

Table 7 Mean density of the common goby, Pomatoschistus microps, in different Atlantic estuaries

\begin{tabular}{|c|c|c|c|c|c|c|}
\hline Location & Mean density $100 \mathrm{~m}^{-2}$ & Study period & Seasons & Day period & Sampling gear & Reference \\
\hline $\begin{array}{l}\text { Sylt-Rømø Bight, } \\
\text { Germany }\end{array}$ & $\begin{array}{l}230.0-1070.0 \text { (seagrass); } \\
30.0-200.0 \text { (sand) }\end{array}$ & 2003 & Summer & Diurnal & $\begin{array}{l}\text { Portable drop } \\
\text { trap }\end{array}$ & Polte et al. 2005 \\
\hline Wadden Sea, Germany & 6.0 & $1991 / 92$ & Summer & $\begin{array}{r}\text { Diurnal and } \\
\text { nocturnal }\end{array}$ & Beam trawl & $\begin{array}{l}\text { Norte-Campos and } \\
\text { Temming } 1994\end{array}$ \\
\hline Canche estuary, France & 8.2 & $2006 / 07$ & All seasons & Diurnal & Beam trawl & $\begin{array}{r}\text { Selleslagh and } \\
\text { Amara } 2008\end{array}$ \\
\hline Minho estuary, Portugal & 118.3 & $2009 / 10$ & All seasons & Diurnal & Beam trawl & This study \\
\hline Minho estuary, Portugal & 60.1 & 2006 & Summer & Diurnal & Beam trawl & Costa-Dias et al. 2010 \\
\hline $\begin{array}{l}\text { Mondego estuary, } \\
\text { Portugal }\end{array}$ & 0.8 & $2003 / 06$ & All seasons & Nocturnal & Beam trawl & Martinho et al. 2007 \\
\hline $\begin{array}{l}\text { Mondego estuary, } \\
\text { Portugal }\end{array}$ & 0.8 & $2003 / 04$ & All seasons & Nocturnal & Beam trawl & Dolbeth et al. 2007 \\
\hline \multirow[t]{2}{*}{ Portugal } & $\begin{array}{l}0.8 \\
0.5\end{array}$ & $\begin{array}{l}2004 / 05 \\
2005 / 06\end{array}$ & $\begin{array}{l}\text { All seasons } \\
\text { All seasons }\end{array}$ & $\begin{array}{l}\text { Nocturnal } \\
\text { Nocturnal }\end{array}$ & $\begin{array}{l}\text { Beam trawl } \\
\text { Beam trawl }\end{array}$ & Leitão et al. 2006 \\
\hline & 0.8 & $2003 / 04$ & All seasons & Nocturnal & Beam trawl & \\
\hline Tagus estuary, Portugal & $\begin{array}{l}60.0 \text { (upper intertidal); } \\
17.1 \text { (lower intertidal); } \\
89.9 \text { (subtidal) }\end{array}$ & 2005 & All seasons & $\begin{array}{r}\text { Diurnal and } \\
\text { nocturnal }\end{array}$ & Encircling nets & França et al. 2008 \\
\hline Ria Formosa, Portugal & 115.0 & $2001 / 02$ & All seasons & - & Throw trap & Almeida et al. 2008 \\
\hline
\end{tabular}


Other studies also reported remarkable high densities of aquatic species in the Minho estuary, for instance, the Asian clam, Corbicula fluminea (Sousa et al. 2008a), the European flounder, Platichthys flesus (Cabral et al. 2007; Freitas et al. 2009; Souza et al. 2013) and the shore crab, Carcinus maenas (Souza et al. unpubl. data). These high densities may be linked to the particular abiotic profile of the Minho estuary, namely the high river discharge and possibly the high availability of nutrients and organic matter. These characteristics may lead to a scenario of dominance of a few species, highly tolerant to freshwater in detriment of species with higher affinity with salt water, suggesting that in stressful environments certain species can be benefited.

Secondary production can be used to infer the population fitness (Rigler and Downing 1984) and therefore, it may represent an interesting proxy with regard to the functional responses of populations to environmental stressors (Dolbeth et al. 2012). The annual production of $P$. microps in the Minho estuary was notably higher than in other systems (see Dolbeth et al. 2010 and the references therein), suggesting that this system provide advantageous environmental conditions for this particular species to thrive. Nonetheless, in a previous study, Dolbeth et al. (2010) recorded production values four times lower for P. microps in the same estuary, suggesting that the common goby production might have increased over the years, probably due to the fluctuations on the abiotic conditions caused by drought events that occurred in this estuary recently (see Dolbeth et al. 2010; Ilarri et al. 2011). Alternatively, differences in production values obtained for $P$. microps in the Minho estuary can be the result of different sampling strategies and production estimation method adopted in each study.

\section{Conclusions}

In summary, our results highlight that the common goby population in the Minho estuary is remarkably dense and productive. This is probably explained by a combination of factors found in the system, such as the low salinity, the prolonged breeding season of $P$. microps, the low density of the competing species $P$. minutus, and the copious availability of suitable substrate for reproduction. In conclusion, the common goby may have found in the Minho estuary an area with a combination of factors that created optimal conditions for it to thrive.

Acknowledgments The authors would like to thank Eduardo Martins and Carlos Antunes for their help during the field campaign in Minho estuary. We would like also to thank Fabiana Freitas, Felipe Ribas, João Moura and Jorge Araújo for their valuable help in the lab, Martina Ilarri and Ronaldo Sousa for reviewing the early version of the manuscript. Special thanks are to the editor Dr. DLG Noakes and three anonymous referees that greatly contributed to the manuscript improvement. This research was approved by the university's ethics committee and was supported by a grant from Iceland, Liechtenstein and Norway through the EEA Financial Mechanism and the Norwegian Financial Mechanism. A.T. Souza has a PhD grant (SFRH/BD/ 71232/2010) from the Fundação para a Ciência e a Tecnologia (Portugal). I. Martins was financed for CIÊNCIA 2007 and the project INPACTAR PTDC/MAR/111537/2009; FCT; COMPETE; QREN; UE.

\section{References}

Able KW (2005) A re-examination of fish estuarine dependence: evidence for connectivity between estuarine and ocean habitats. Estuar Coast Shelf Sci 64:5-17

Almeida C, Coelho R, Silva M, Bentes L, Monteiro P, Ribeiro J, Erzini K, Gonçalves JMS (2008) Use of different intertidal habitats by faunal communities in a temperate coastal lagoon. Estuar Coast Shelf Sci 80:357-364

Anderson MJ (2001) A new method for non-parametric multivariate analysis of variance. Austral Ecol 26:32-46

Anderson MJ, Gorley RN, Clarke KR (2008) PERMANOVA + for PRIMER: guide to software and statistical methods. PRIMER-E, Plymouth

Antunes C, Rodrigues H (2004) Guia Natural do Rio Minho. Os Peixes. Aquamuseu do Rio Minho, Vila Nova de Cerveira

Arruda LM, Azevedo JN, Neto AI (1993) Abundance, agestructure and growth, and reproduction of Gobies (Pisces; Gobidae) in the Ria de Aveiro Lagoon (Portugal). Estuar Coast Shelf Sci 37:509-523

Bouchereau JL, Guelorget O (1998) Comparison of three Gobiidae (Teleostei) life history strategies over their geographical range. Oceanol Acta 24:503-517

Bouchereau JL, Joyeux JC, Quignard JP (1989) La reproduction de Pomatoschistus microps (Kroyer, 1938), Poissons, Gobiides, dans la lagune de Mauguio. (France). B Ecol 20:193-202

Bouchereau JL, Quignard JP, Joyeux JC, Tomasini JA (1993) Structure du stock des géniteurs de la population de Pomatoschistus microps (Kroyer, 1838) (Gobiidae), dans la lagune de Mauguio, France. Cybium 17:3-15

Cabral HN (2000) Comparative feeding ecology of sympatric Solea solea and $S$. senegalensis, within the nursery areas of the Tagus estuary, Portugal. J Fish Biol 57:1550-1562

Cabral HN, Vasconcelos R, Vinagre C, França S, Fonseca V, Maia A, Reis-Santos P, Lopes M, Ruano M, Campos J, Freitas V, Santos PT, Costa MJ (2007) Relative importance of estuarine flatfish nurseries along the Portuguese coast. J Sea Res 57:209-217 
Chambers JR (1992) Coastal degradation and fish population losses. In: Stroud RS (ed) Stemming the tide of coastal fish habitat loss. National Coalition for Marine Conservation Inc., Leesburg, pp 45-51

Clarke KR, Gorley RN (2006) PRIMER v6: user manual/tutorial. PRIMER-E, Plymouth

Costa-Dias S, Freitas V, Sousa R, Antunes C (2010) Factors influencing epibenthic assemblages in the Minho Estuary (NW Iberian Peninsula). Mar Pollut Bull 61:240-246

Dempster AP, Laird NM, Rubin DB (1977) Maximum likelihood from incomplete data via EM algorithm. J Roy Stat Soc B 39: $1-38$

Dolbeth M, Martinho F, Leitão R, Cabral H, Pardal M (2007) Strategies of Pomatoschistus minutus and Pomatoschistus microps to cope with environmental instability. Estuar Coast Shelf Sci 74:263-273

Dolbeth M, Martinho F, Freitas V, Costa-Dias S, Campos J, Pardal MA (2010) Multi-year comparisons of fish recruitment, growth and production in two drought-affected Iberian estuaries. Mar Freshw Res 61:1399-1415

Dolbeth M, Cusson M, Sousa R, Pardal MA (2012) Secondary production as a tool for better understanding of aquatic ecosystems. Can J Fish Aquat Sci 69:1230-1253

Doornbos G (1984) Piscivorous birds on the saline Lake Grevelingen, The Netherlands: abundance, prey selection and annual food consumption. Neth J Sea Res 18:457-479

Fonds M, Van Buurt G (1974) The influence of temperate and salinity on development and survival of goby eggs (Pisces, Gobiidae). Hydrobiol Bull 8:110-116

Fouda MM, Hanna MY, Fouda FM (1993) Reproductive biology of a Red Sea goby, Silhouettea aegyptia, and a Mediterranean goby, Pomatoschistus marmoratus, in Lake Timsah, Suez Canal. J Fish Biol 43:139-151

França S, Pardal MA, Cabral H (2008) Mudflat nekton assemblages in the Tagus estuary (Portugal): distribution and feeding patterns. Sci Mar 72(3):591-602

Freitas F (2011) Populations dynamics of Crangon crangon: latitudinal comparative study. Master thesis, Universidade de Aveiro

Freitas V, Costa-Dias S, Campos J, Bio A, Santos P, Antunes C (2009) Patterns in abundance and distribution of juvenile flounder Platichthys flesus, in Minho estuary (NW Iberian Peninsula). Aquat Ecol 43:1143-1153

Froese R, Pauly D (2010) FishBase. World Wide Web electronic publication. www. fishbase.org. Accessed 4 February 2010.

Fuiman LA, Cowan-Jr JH, Smith ME, O’Neal JP (2005) Behavior and recruitment success in fish larvae: variation with growth rate and the batch effect. Can J Fish Aquat Sci 62:1337-1349

Guimarães L, Medina MH, Guilhermino L (2012) Health status of Pomatoschistus microps populations in relation to pollution and natural stressors: implications for ecological risk assessment. Biomarkers 17(1):62-77

Ilarri MI (2012) Functional importance of the Asian clam Corbicula fluminea in invaded ecosystems. PhD thesis, Universidade do Porto

Ilarri MI, Antunes C, Guilhermino L, Sousa R (2011) Massive mortality of the Asian clam Corbicula fluminea in a highly invaded area. Biol Invasions 13:277-280

Jackson AC, Rundle SD (2008) Diet-shifts by an estuarine goby (Pomatoschistus microps) in the face of prey availability. $\mathrm{J}$ Exp Mar Biol Ecol 361:1-7
Koutrakis ET, Tsikliras AC (2009) Reproductive biology of the marbled goby, Pomatoschistus marmoratus (Pisces: Gobiidae), in a northern Aegean estuarine system (Greece). Folia Zool 58(4):447-456

Koutsogiannopoulou V, Wilson JG (2007) The fish assemblage of the intertidal salt marsh creeks in North Bull Island, Dublin Bay: seasonal and tidal changes in composition, distribution and abundance. Hydrobiologia 588:213-224

Krueger CC, Martin FB (1980) Computation of confidence intervals for size-frequency (Hynes) method of estimating secondary production. Limnol Oceanogr 25(4):773-777

Legendre P, Anderson MJ (1999) Distance-based redundancy analysis: testing multispecies responses in multifactorial ecological experiments. Ecol Monogr 69:1-24

Leitão R, Martinho F, Neto JM, Cabral H, Marques JC, Pardal MA (2006) Feeding ecology, population structure and distribution of Pomatoschistus microps (Krøyer, 1838) and Pomatoschistus minutus (Pallas, 1770) in a temperate estuary. Portugal. Estuar Coast Shelf Sci 66:231-239

Magnhagen C (1998) Alternative reproductive tactics and courtship in the common goby. J Fish Biol 53:130-137

Martinho F, Leitão R, Viegas I, Dolbeth M, Neto JM, Cabral HN, Pardal MA (2007) The influence of an extreme drought event in the fish community of a southern Europe temperate estuary. Estuar Coast Shelf Sci 75(4):537-546

Mehner T (1992) Diet spectra of Pomatoschistus microps (Kroyer) and Pomatoschistus minutus (Pallas) (Teleostei, Gobiidae) during first weeks after hatching. Zool Anz 229:13-20

Miller PJ (1975) Age structure and life-span in the common goby Pomatoschistus microps. J Zool Lond 177:425-448

Miller PJ (1984) The tokology gobioid fishes. In: Potts GW, Wootton JR (eds) Fish reproduction: strategies and tactics. Academic, London, pp 119-153

Monteiro M, Quintaneiro C, Nogueira AJ, Morgado F, Soares AM, Guilhermino L (2007) Impact of chemical exposure on the fish Pomatoschistus microps Krøyer (1838) in estuaries of the Portuguese Northwest coast. Chemosphere 66(3):514-522

Moreira F, Assis CA, Almeida PR, Costa JL, Costa MJ (1992) Trophic relationships in the community of the upper Tagus estuary (Portugal): a preliminary approach. Estuar Coast Shelf Sci 34(6):617-623

Moreno J, Fatela F, Andrade C, Cascalho J, Moreno F, Drago T (2005) Living foraminiferal assemblages from the Minho and Coura estuaries (Northern Portugal): a stressful environment. Thalassas 21:17-28

Nelson DM, Monaco ME (2000) National overview and evolution of NOAA's Estuarine Living Marine Resources (ELMR) Program. NOAA Tech. Memo. NOS NCCOS CCMA 144. NOAA, NOS, Center for Coastal Monitoring and Assessment, Silver Spring

Norte-Campos AGC, Temming A (1994) Daily activity, feeding and rations in gobies and brown shrimp in the northern Wadden Sea. Mar Ecol Prog Ser 115:41-53

Nyman KJ (1953) Observations on the behavior of Gobious microps. Acta Soc Fauna Flora Fenn 69:1-11

Oliveira M, Gravato C, Guilhermino L (2012) Acute toxic effects of pyrene on Pomatoschistus microps (Teleostei, Gobiidae): mortality, biomarkers and swimming performance. Ecol Indic 19:206-214 
Pampoulie C (2001) Demographic structure and life history traits of the common goby Pomatoschistus microps (Teleostei, Gobidae) in a Mediterranean coastal lagoon (Rhône River delta, France). Acta Oecol 22:253-257

Pampoulie C, Rosecchi E, Bouchereau JL, Crivelli AJ (1999) Life history traits of Pomatoschistus minutus (Teleostei, Pisces) in the Rhône Delta, France. J Fish Biol 55:892-896

Pampoulie C, Bouchereau JL, Rosecchi E, Poizat G, Crivelli AJ (2000) Annual variations in the reproductive traits of Pomatoschistus microps in a Mediterranean lagoon undergoing environmental changes: evidence of phenotypic plasticity. J Fish Biol 57:1441-1452

Polte P, Schanz A, Asmus H (2005) The contribution of seagrass beds (Zostera noltii) to the function of tidal flats as a juvenile habitat for dominant, mobile epibenthos in the Wadden Sea. Mar Biol 147:813-822

Reiss MJ (1989) The allometry of growth and reproduction. Cambridge University Press, Cambridge

Ribeiro J, Bentes L, Coelho R, Gonçalves JMS, Lino PG, Monteiro P, Erzini K (2006) Seasonal, tidal and diurnal changes in fish assemblages in the Ria Formosa lagoon (Portugal). Estuar Coast Shelf Sci 67:461-474

Rigler FH, Downing JA (1984) The calculation of secondary productivity. In: Rigler FH, Downing JA (eds) A manual on methods for the assessment of secondary productivity in fresh waters. Blackwell Scientific Publications, Oxford, pp $19-58$

Rogers SI (1988) Reproductive effort and efficiency in the female common goby. Pomatoschistus microps (Krøyer) (Teleostei: Gobioidei). J Fish Biol 33:109-119

Rotherham D, Gray C, Johnson D, Lokys P (2008) Effects of diel period and tow duration on estuarine fauna sampled with a beam trawl over bare sediment: consequences for designing more reliable and efficient surveys. Estuar Coast Shelf Sci 78:179-189

Selleslagh J, Amara R (2008) Environmental factors structuring fish composition and assemblages in a small macrotidal estuary (eastern English Channel). Estuar Coast Shelf Sci 79:507-517

Sousa R, Guilhermino L, Antunes C (2005) Molluscan fauna in the freshwater tidal area of the river Minho estuary, NW of Iberian Peninsula. Ann Limnol 41:141-147
Sousa R, Nogueira AJA, Gaspar M, Antunes C, Guilhermino L (2008a) Growth and extremely high production of the nonindigenous invasive species Corbicula fluminea (Müller, 1774): possible implications for ecosystem functioning. Estuar Coast Shelf Sci 80:289-295

Sousa R, Rufino M, Gaspar M, Antunes C, Guilhermino L (2008b) Abiotic impacts on spatial and temporal distribution of Corbicula fluminea (Müller, 1774) in the River Minho estuary, Portugal. Aquat Conserv Mar Freshw Ecosyst 18:98-110

Sousa R, Dias S, Freitas V, Antunes C (2008c) Subtidal macrozoobenthic assemblages along the River Minho estuarine gradient (north-west Iberian Peninsula). Aquat Conserv Mar Freshw Ecosyst 18:1063-1077

Souza AT, Ilarri MI, Campos J, Marques JC, Martins I (2011) Differences in the neighborhood: structural variations in the carapace of shore crabs Carcinus maenas (Decapoda: Portunidae). Estuar Coast Shelf Sci 95:424-430

Souza AT, Dias E, Nogueira A, Campos J, Marques JC, Martins I (2013) Population ecology and habitat preferences of juvenile flounder Platichthys flesus (Actinopterigyii: Pleuronectidae) in a temperate estuary. J Sea Res 79:60-69

Vieira LR, Sousa A, Frasco MF, Lima I, Morgado F, Guilhermino L (2008) Acute effects of Benzo[a]pyrene, anthracene and a fuel oil on biomarkers of the common goby Pomatoschistus microps (Teleostei, Gobiidae). Sci Total Environ 395(2-3):87-100

Vieira LR, Gravato C, Soares AMVM, Morgado F, Guilhermino L (2009) Acute effects of copper and mercury on the estuarine fish Pomatoschistus microps: linking biomarkers to behaviour. Chemosphere 76(10):1416-1427

Whitehead PJP, Bauchot ML, Hureau JC, Nielsen J, Tortonese E (1986) Fishes of the north-eastern Atlantic and the Mediterranean. UNESCO, Paris

Wiederholm A-M (1987) Distribution of Pomatoschistus minutus and P. microps (Gobiidae, Pisces) in the Bothnian sea: importance of salinity and temperature. Memo Soc Fauna Flora Fenn 63:56-62

Złoch I, Sapota MR (2010) Trophic interactions between preadult and adult Pomatoschistus minutus and Pomatoschistus microps and young Platichthys flesus occurring in inshore waters of the Gulf of Gdansk (Southern Baltic). Oceanol Hydrobiol St 39(2):37-53 